\title{
OBSERVATION OF HOLLOWS IN THE SNOW SURFACE OF TORV GLETSCHER, EAST GREENLAND
}

\author{
By John RuckLIDGe \\ (Department of Geology and Mineralogy, University of Oxford, Oxford, England)*
}

Abstract. Many elongated hollows about $300 \mathrm{~m}$. long, $200 \mathrm{~m}$. wide and $30 \mathrm{~m}$. deep occur on the surface of Torv Gletscher in a region where the flow of the glacier splits in several directions. Their possible origin is discussed.

RÉsumé. Observation de creux à la surface de la neige du Torv Gletscher, Groenland Est. Beaucoup de creux alongés d'environ $300 \mathrm{~m}$ de long, $200 \mathrm{~m}$ de large et $30 \mathrm{~m}$ de profondeur existent à la surface du Torv Gletscher dans une zone où l'écoulement du glacier éclate en plusieurs directions. Leur origine possible est discutée.

Zusammenfassung. Beobachtungen an Eintiefungen in der Schneeoberfläche des Torv-Gletschers, Ost-Grönland. Auf der Oberfläche des Torv-Gletschers treten viele längliche Eintiefungen auf, die etwa $300 \mathrm{~m}$ lang, $200 \mathrm{~m}$ breit und $30 \mathrm{~m}$ tief sind. Sie liegen in einem Gebiet, wo sich der Gletscherstrom in mehrere Richtungen aufspaltet. Ihre mögliche Entstehung wird diskutiert.

In the course of the Oxford University Expedition to East Greenland ig65, a party sledged the length of Torv Gletscher, which runs parallel to Scoresby Sund on its south side. At a position approximately lat. $70^{\circ} \mathrm{oo}^{\prime} \mathrm{N}$., long. $23^{\circ} 55^{\prime} \mathrm{W}$., $45 \mathrm{~km}$. from the snout of the glacier, and at an altitude of $1,050 \mathrm{~m}$. $(250 \mathrm{~m}$. above the firn line) a series of hollows were encountered in the surface of the snow.

The hollows, which are seen from the air in Figure I, are approximately elliptical in shape and have

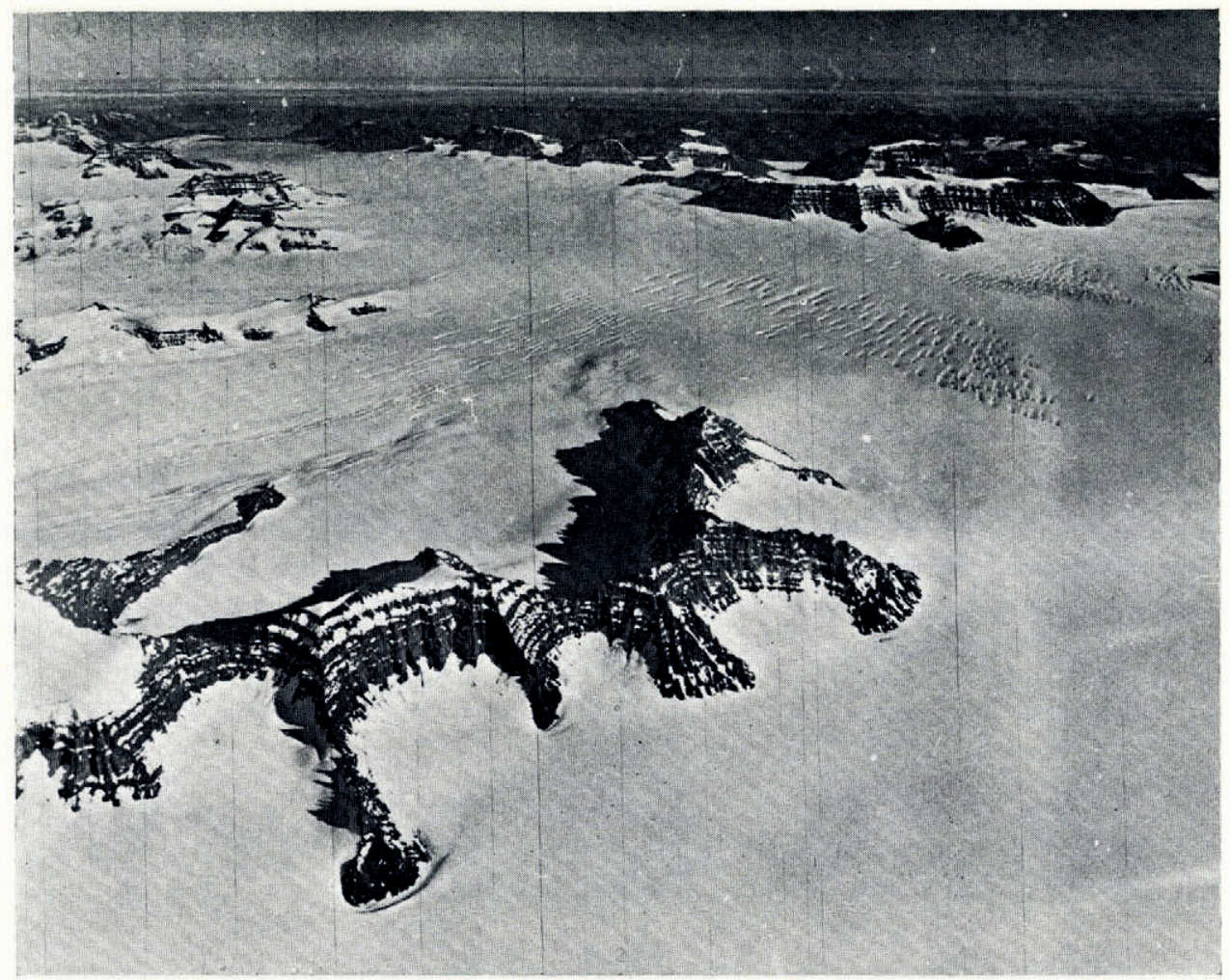

Fig. I. Aerial view of the hollows from the north-west, taken II August 195I. (Copyright. Geodetic Institute, Denmark)

* Present address: Department of Geology, University of Toronto, Toronto, Ontario, Canada. 
their long axes oriented in a northerly direction. The depressions are similar in shape and form, the major axis of each ellipse being some $500 \mathrm{~m}$. and the minor $200 \mathrm{~m}$. The hollows reach a depth of about $30 \mathrm{~m}$. at the northern end and steep slopes $\left(a b o u t 60^{\circ}\right)$ rise above the lowest point on the north and east. The slopes of the other sides of the trough are gentle enough to walk up. The eastern flank is the steeper and is covered more densely by airborne debris. The steepest slopes consist of stratified snow, while elsewhere no banding is seen. These features are illustrated in Figures 2 and 3 .

The swarm of hollows occurs in a region of tension where the flow of the glacier splits in several directions. A proposed flow pattern is given in Figure 4. A crevasse belt occurs on the north side of Torv Gletscher where the level descends to Vestre Borggletscher, and another on the south side towards Stenos Gletscher, but the major swarm of hollows is not associated with either of these. The shapes and positions of the hollows do not appear to have changed much since $195 \mathrm{I}$ when the aerial photograph was taken, to the time when these observations were made in August 1965. Torv Gletscher probably flows very slowly, to judge from the amount of calving which was observed and the extent of dead ice in its lower reaches. The ice cap which feeds this glacier is of very limited extent, and it also feeds a number of other glaciers in the region.

The explanation of the origin of these hollows must lie in the conditions which are peculiar to this particular locality. The exposure of stratification layers in the steepest slopes favours an origin in crevasse-type opening rather than slumping or surface deformation which may be suggested by the general shape of the structures. It is proposed that the central region of the glacier where the hollows occur probably moves very slowly in relation to the ice on the north and south sides, where the flow is channelled into distributary glaciers. In the first place the hollows may exist as a belt of crevasses at the western end of the area covered by the present swarm, and two crevasses were observed running northsouth across the glacier in this area. A crevasse in the relatively stationary central ice will develop differently from one in a similar position on the north or south flanks where dynamic changes will take place. Instead, crevasses in the centre may become filled with snow, but the depression on the surface will in time be affected by microclimotological effects. Wind-blown dust may be expected to accumulate on the eastern side of a depression, assuming a westerly, probably katabatic wind. There will be differential absorbtion of radiation, which will tend to deepen the trough, and steepen the eastern slopes.

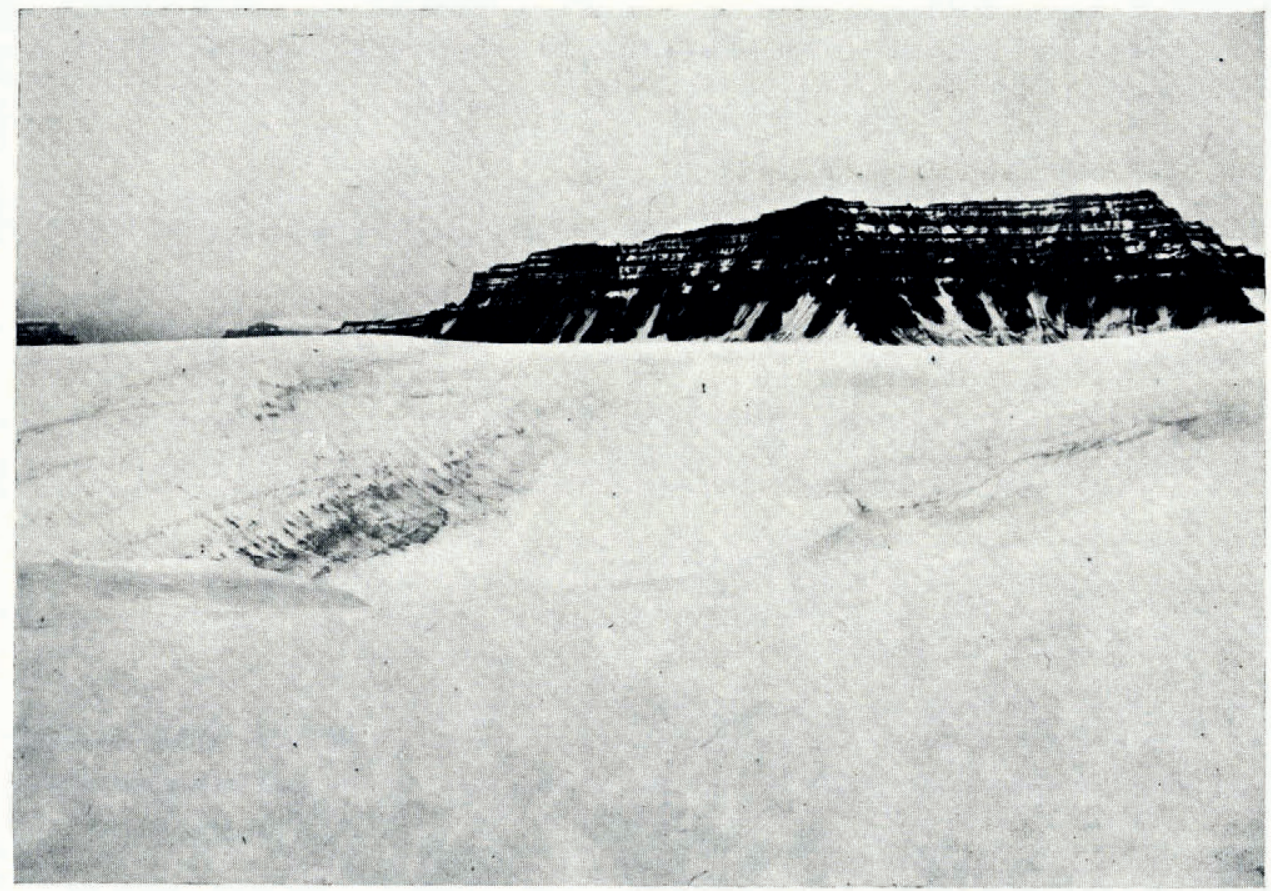

Fig. 2. A typical hollow seen from its northern end 

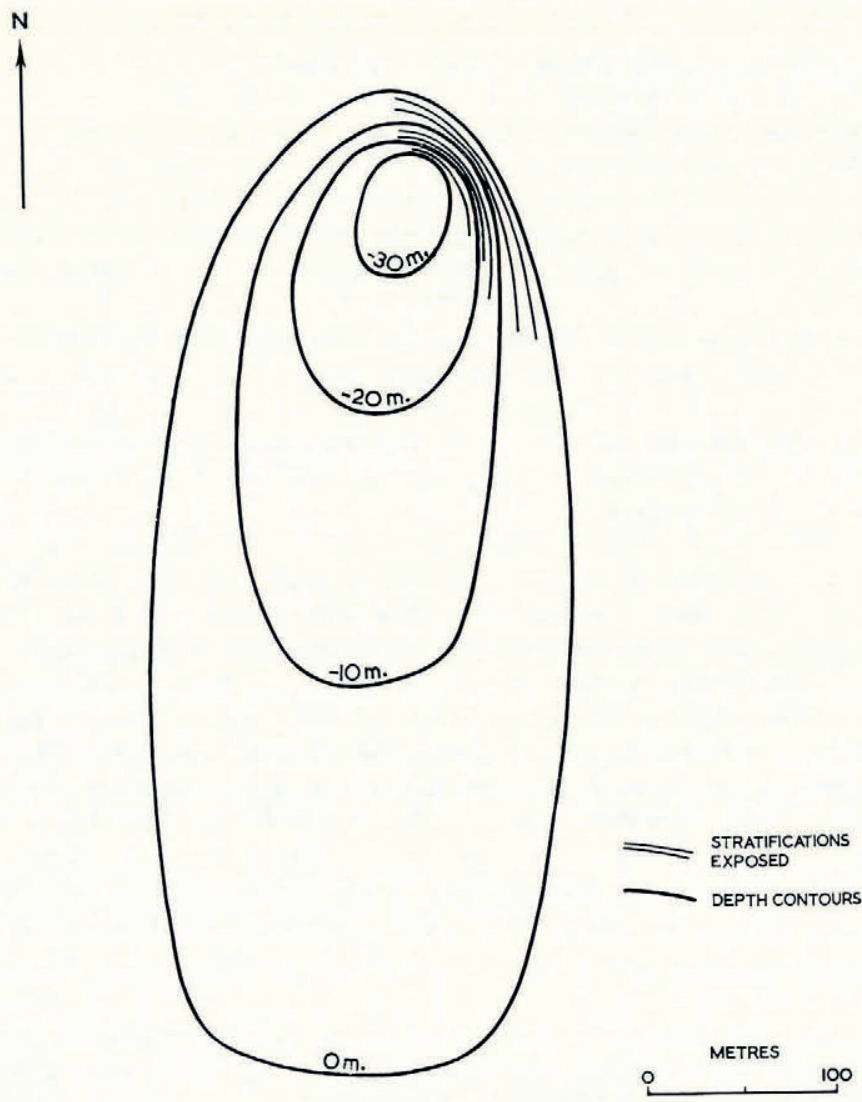

Fig. 3. Sketch contour map of a typical hollow
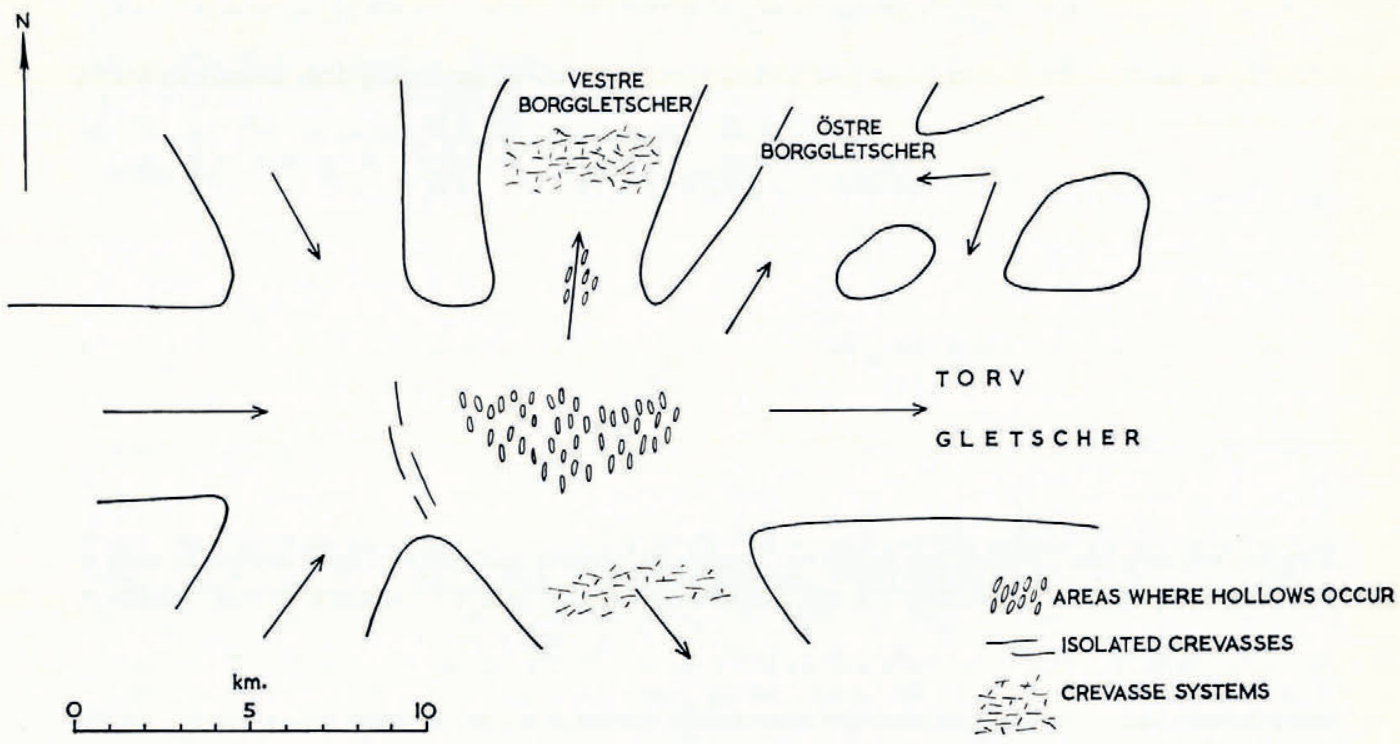

Fig. 4. Ice-flow pattern in the region of the hollows 
The slopes at the northern end will be steepened in a similar way because the sun shines most strongly from the south. The perpetuation of the phenomena thus appears reasonable, but the hypothesis concerning their origin remains tentative. It is interesting to speculate that these features may be characteristic of regions of glaciers above the firn line where for some reason the flow has been retarded.

MS. received 8 February 1966 